\title{
Factors Influencing Tobacco Leaf Quality: an Investigation of the Literature *
}

\author{
by S. Mendell, E. C. Bourlas and M. Z. DeBardeleben
}

Pbilip Morris Research Center, Richmond, Virginia, U.S.A.

\section{SUMMARY}

This paper comprises a review of the published literature (1936-1979) dealing with the relationship between the chemical constituents of tobacco and smoke and tobacco and smoke quality. Various components thought to be influential in determining quality are identified; conclusions of researchers regarding the effects of these components are recorded and discussed. A summary table is presented which details the nature of the relationship between these constituents and tobacco quality.

\section{ZUSAMMENFASSUNG}

In einem zusammenfassenden Ūberblick wird die in den Jahren 1936 bis 1979 veröffentlichte Literatur über die Beziehungen $z$ wischen den chemischen Bestandteilen von Tabak und Rauch einerseits und der Tabakund Rauchqualität andererseits dargestellt. Verschied ene Komponenten, denen in den betreffenden Aufsätzen eine Bedeutung für die Qualität zugeschrieben wurde, werden hinsichtlich ihrer Wirksamkeit im einzelnen behandelt, wobei die Schlußfolgerungen der Autoren aufgeführt und diskutiert werden. Die in den einzelnen Arbeiten angegebene Bedeutung der Bestandteile für die Tabakqualitāt wird in einer zusammenfassenden Tabelle bewertend charakterisiert.

\footnotetext{
* Received: 7th Seprember 1982 - accepted: 21 st October 1983.
}

\section{RESUME}

Cet article donne un vaste panorama de la littérature publiće au cours des années 1936 à 1979 concernant les relations existantes entre d'une part les composants chimiques du tabac et de la fumée et d'autre part la qualité du tabac et de la fumée. Différents composants auxquels ces articles accordent une signification eu égard à la qualité, sont traités dans le détail du point de vue de leur efficacité, les conclusions des auteurs étant citées et discutées. L'influence de ces composants sur la qualité du tabac telle qu'elle est indiquée dans les différents travaux est présentée et spécifiée dans un tableau récapitulatif.

\section{IN'TRODUCTION}

A great deal of research has been conducted over the years regarding the relationship between the chemical constituents of tobacco and smoke and tobacco and smoke quality. This paper attempts to survey the literature in the area of cigarette tobacco, noting the effects of various components thought to be influential in determining quality. This review encompasses studies reported between 1936 and 1979, including many foreign contributions. Studies that have not been cited directly here are included in a general "Bibliography". This paper is intended to serve as a starting point from which to conduct future investigations of the topic.

Unfortunately, one of the major obstacles in attempting 
to correlate the results of these various investigations remains the lack of consensus on a definition of quality. This is an issue with which Coresta ${ }^{*}$ has wrestled for many years. Akehurst ${ }^{+}$has suggested that quality may be "that for which the buyer pays money". Tso ${ }^{++}$gives the following definition: "Many essential chemical and physical characteristics are being used to judge quality. In flue-cured tobacco these characteristics may be classified into three areas:

1. Visible and detectable criteria: size, uniformity, finish, foreign matter, damage, color, texture (grainy, soft), body (thickness, density), maturity, odor and flavor;

2. Physical criteria: filling power, shatter resistance, equilibrium moisture content, strip yield, combustibility and stalk position; and

3. Chemical criteria: nicotine, sugar, petroleum ether extracts, mineral components, alkalinity of water-soluble ash, total $N$, protein $N$, $\alpha$-amino $N$, starch, nonvolatile acids, and total volatile bases.

Most of these characteristics may also be used to judge the quality of other tobacco types. The ultimate judgment, however, is based on smoking taste and odor, generally known as strength, aroma, mildness or sharpness".

This paper is concerned with investigations of the latter aspect of quality, i.e. chemical criteria. However, the many researchers working in this area often do not bother to define what they mean by quality, but merely proceed to speak in terms of "quality" as a self-evident attribute. The problem is further complicated because the research involves many different types of tobacco, grown in many different areas under many different types of agricultural conditions. Furthermore, tastes have varied not only around the world but throughout time. In addition to these other factors, the influence of stalk position must also be considered. Thus, investigators offer necessarily contradictory and confusing evidence with regard to the effects contributed by the chemical constituents in question, rendering conclusive judgments impossible (see Summary Table 1).

Often it is not an absolute quantity of a substance which is important, but the relative amount of the particular constituent and its balance with other factors. Attempts to develop quality indices relating these elements have resulted in a myriad of formulas which cannot be applied uniformly to tobacco of different types or regions. Nor can they be applied unchanged over time, since the increasing sophistication of analytical

\footnotetext{
* Cooperation Centre for Scientific Research relative to Tobacco, Paris.

+ Akehurst, B. C.: Tobacco; Longman, London and New York, 1st edition, 1968, p. 457.

* Tso, T. C.: Physiology and biochemistry of tobacco plants; Dowden, Hutchinson \& Ross, Inc., Stroudsburg, P2, 1972, p. 305.
}

tools and methods presents data that continue to become more precise. Indeed, as Akeburst ** has stated, "undoubtedly the behavior of tobacco leaf in manufacture and smoking is the result of numerous interactions between a large number of compounds, but to pick out a small number and express their relationship as a general quality index is only likely to be of limited local usefulness".

Thus, this paper does not attempt to draw firm conclusions regarding the effects of specific substances on the nebulous attribute referred to as tobacco "quality". Nevertheless, it does serve both to identify those components of tobacco thought to be influential in determining quality and to focus on the complexity of their interactions.

\section{CHEMICAL COMPONENTS AND QUALITY}

\section{Acids}

Acids are an important constituent of tobacco. They help regulate the $\mathrm{pH}$ of tobacco, thus indirectly influencing smoke aroma and taste. Acids in general have been reported to have varying degrees of association with quality, including no association at all, Kallianos has stated that confusion may exist because acids predominate in tobacco as salts and the taste effects come from thermal degradation of the salts (26).

High acid concentrations have been found in light-bodied leaves, low concentrations in heavy-bodied leaves (1). Shmuk reports that high acid content indicates high ash content which has been correlated with poorer taste and combustibility. He also states that acid fractions do not influence aroma, but do improve and mellow the taste (66).

There seems to be no consistent relationship between total organic acids and quality $(26,56,58,63)$, though several sources have indicated that non-volatile carboxylic acids (especially malic, citric, oxalic and malonic) have an inverse relationship with taste $(26,49,66)$. Volatile organic acids such as formic, acetic, propionic or isobutyric, however, are especially important in contributing to smoke flavor and aroma $(1,2,26)$. Non-volatile acids are also quality producing agents (3), as are aromatic acids, especially benzoic acid and phenylacetic acid (67). However, water-soluble acids have not been consistently linked to quality (63).

Fatty acids have a significant relationship with quality. The major higher fatty acids are: palmitic, linoleic, linolenic, stearic, oleic, myristic and lauric. Ethyl and methyl esters of the higher fatty acids are smoothing; some esters of the lower fatty acids add fruity, winey and waxy flavors (13). Davis and Kallianos have each suggested that low molecular weight fatty acids contribute significantly to smoke flavor, quality and aroma $(13,26)$.

\footnotetext{
** Akehurst, B. C.: Tobacco; Longman, London and New York, 1st edi-
} tion, 1968, p. 448. 


\section{Alkaloids}

Alkaloids contribute to smoke flavor (2) and have a significant positive correlation with taste (25). They are a common determinant of quality (22). In general a lower alkaloid content indicates higher quality; higher concentrations lead to stronger "gustatory" sensations (66). Alkaloids have been negatively related to mildness and palatability, positively correlated with "smoking density" (38).

Nicotine, the most important alkaloid in tobacco, determines the physiological strength of tobacco and smoke $(1,66)$ and therefore has a significant positive correlation with taste strength $(25,66)$. Nicotine salts are thought to be particularly important for determining sensory strength (65).

Reports on nicotine's role in determining tobacco quality vary. Free nicotine and bound nicotine apparently have different effects on flavor (2). Some sources indicate a definite negative correlation between nicotine and tobacco quality $(17,68)$; others classify nicotine as a quality producing chemical (3); still others cite no consistent relationship between nicotine content and quality $(20,58,63)$. It has been suggested though, by both $A$ hmad (3) and Chakraborty (11), that it is the balance between nicotine, nitrogen and sugar in the leaf which regulates the quality of the smoke, indicating that too much nicotine can be as undesirable as too little (49).

Nicotine appears in high concentrations in Burley tobacco, low in flue-cured and lowest or in-between in Oriental. It seems to have a positive effect on the quality of air-cured tobacco and a negative effect on that of flue-cured (12).

Nornicotine, another important alkaloid, has been negatively correlated with quality (15).

\section{Carbohydrates}

Carbohydrates are significant chemical constituents of tobacco. In general they contribute to smoke flavor (2, 66) and have a positive influence on tobacco quality (1, $17,19,50,55,56,66)$. However, increasing the carbohydrate concentration does not lead to further improvements in quality unless accompanied by the harmonious interaction of other components $(1,66)$. For example, sugars, which most sources indicate have a positive correlation with quality and taste, appear in higher concentrations in desirable leaves, but they do not imply high quality unless enough waxes and resins are present $(56,61)$. Sugars often must be added to tobacco to balance acidic and alkaline substances (1), however too much sugar can lead to a biting or pungent smoke $(56,61)$. In other words, there can be too high as well as too low a level of carbohydrates.

Carbohydrate content varies with tobacco type, being high in flue-cured tobacco, low in Burley and Maryland, and in-between in Oriental (1). Carbohydrate content has been related to a biting taste in Japanese to- bacco smoke and is also an influential contributor to the taste of Turkish tobacco smoke $(17,56)$.

Soluble carbohydrates add to smoke acidity, increase moisture content and retard burning (1), but too high a soluble carbohydrate content weakens the smoke (1, 20). Pyriki's 1958 study showed that soluble carbohydrates, especially monosaccharides, constitute important factors in many quality indices (57). On the other hand, structural carbohydrates, according to Abdallah, have a negative influence on smoke, although they do improve combustibility and filling power (1). Cellulose is also important in promoting combustibility (1), but it has an inverse relationship with quality in general $(20$, 56).

Both Sbmuk and Abdallab agree that pectins have a negative influence on tobacco quality $(1,66)$. Shmuk has stated that not only are pectins negatively correlated with taste, but methyl alcohol, "a component of the pectic substances", has an especially strong negative correlation (66). However, in a 1959 paper, Pyriki reported that pectins may act positively on tobacco, much the same as sugars do (56). In 1963, Pyriki devoted a rather extensive paper to investigations of the relationship between tobacco quality and pectins, but was unable to establish any definite relationship (53).

The role of starches in determining tobacco quality is also questionable. Although $\mathrm{Abmad}$ reports a quality producing effect (3), others describe no consistent relationship $(58,63)$.

\section{Carbonyl Compounds}

Carbonyl compounds such as aldehydes and kețones appear to have a dual effect on aroma. According to one Russian source, the quality of tobacco aroma increases with increasing amounts of carbonyl compounds, especially the non-volatile carbonyls (14). Another Russian study reports that, while non-volatile carbonyl compounds do have a positive influence on aroma, volatile carbonyl compounds contribute an unpleasant odor (32). Like other carbonyl compounds, it seems that some aldehydes have quality producing effects, while others are negatively related to tobacco quality. According to Abdallab, both aldehydes and ketones contribute to smoke flavor (2) and determine reducing power (1), which Shmuk maintains correlates with taste and aroma (66). Additional evidence comes from a 1973 communication in which Kamensbcbikova and Mokbnachev reported that the formaldehyde content of tobacco decreased as the tobacco quality declined (27).

\section{Ether and Petroleum Etber Extracts}

Petroleum ether extracts from tobacco consist mostly of fatty and resinous materials, essential oils, paraffin hydrocarbons, some organic acids, higher alcohols, and 
Table 1. Llterature references (1936-1979) concerning the relationship between tobacco components and quality.

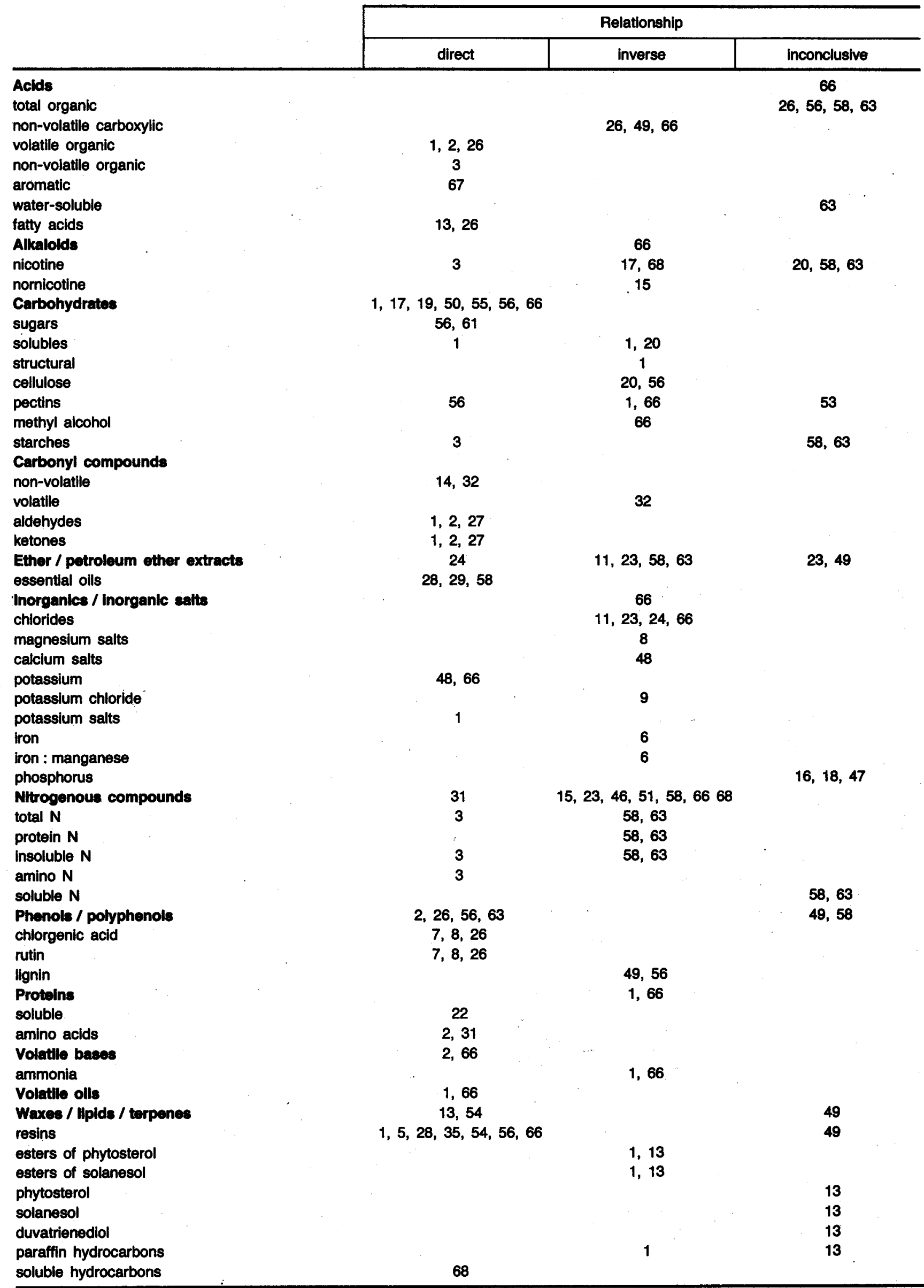


phenols. The extract comprised of essential oils favorably influences quality (58). In general, the more essential oils there are, the better the quality $(28,29)$. The relationship between the neutral essential oil fraction and the basic fraction probably determines leaf quality (28).

Hsieb has argued that theoretically there should be a positive correlation between petroleum ether extracts and quality, but this has never been demonstrated (23). On the contrary, Pbillips and Bacot found no direct relationship (49), while several other sources have reported a negative relationship $(11,23,58,63)$. Hsieb has also stated that a higher level of ether extracts indicates better quality (24), but Phillips and Bacot again found no direct relationship between the two (49).

\section{Inorganics and Inorganic Salts}

Shmuk reports that high concentrations of inorganic salts are undesirable for tobacco quality and combustibility (66). Chlorides depress combustion (9) and generally retard burning $(1,60,62)$, therefore low chloride content correlates with high combustibility which favors good taste (66). Hsieh has found that high grades of tobacco seem to have lower concentrations of chloride $(23,24)$. A recent study on flue-cured tobacco from India, Thailand and Brazil also found an inverse relationship between chloride content and quality (11).

Sabir, studying flue-cured Iraqi tobacco, found that both calcium and magnesium salts improved the moisture content of tobacco (60), but generally, though magnesium and calcium salts play an important role in the burning process $(1,9)$, they are thought to be inversely related to quality (48).

Potassium correlates highly with high combustibility (1, $60,62,66)$ which favors good quality and good taste $(48,66)$. Potassium salts also favor combustion (1). Potassium chloride in large amounts inhibits combustibility, but small amounts of potassium chloride, especially in the presence of calcium and magnesium, promote combustion (9).

In a study of flue-cured tobacco conducted during the 1970's, Araiba and Honda found low iron content and a low iron-to-manganese ratio to be desirable for producing good aroma and taste in tobacco (6).

Another inorganic, phosphorus, has been related to the biting taste in Japanese tobacco smoke. It is reported to have both a positive relation and no correlation at all with quality $(16,18,47)$.

\section{Nitrogenous Compounds}

Nitrogenous compounds, another important group of chemical constituents found in tobacco, have been cited as indices to the strength, smoking, and blending quality of Burley tobacco (34). Generally, nitrogenous compounds are thought to be inversely related to quality $(15,23,46,51,58,66,68)$. As nitrogen content decreases, it leads to a milder, yet poorer, taste (30). Ni- trogenous materials have been related to a biting taste in Japanese tobacco smoke (17). Nitrogen is also unfavorable for burning (62). It has been reported that total nitrogen, protein nitrogen and insoluble nitrogen are unfavorable for quality in Indian flue-cured tobacco $(58,63)$.

However, A $\mathrm{bmad}$ has indicated that total nitrogen, amjno nitrogen and insoluble nitrogen are quality producing agents for flue-cured tobacco (3). Soluble nitrogen has not been related to quality $(58,63)$.

Leffingwell's 1976 paper provides a comprehensive review of the role of nitrogen in determining tobacco quality. The browning reactions which involve nitrogen compounds contribute significantly to tobacco flavor and aroma (31).

\section{Phenols and Polyphenols}

Abdallab and Kallianos both report that phenols may contribute to smoke flavor, quality and aroma $(2,26)$, however, the relationship between quality and complex phenolics is unknown. They may serve as precursors of flavorants (26).

Polyphenols contribute to smoke flavor (2), but like many other substances they appear to have a confusing relationship with tobacco quality. Some sources cite no consistent relationship between polyphenols and tobacco quality $(49,58)$. Others indicate polyphenols are a positive factor in determining quality as long as they are present in smaller concentrations than soluble carbohydrates $(56,63)$; higher concentrations can produce negative effects (66). In a study reported in 1966, Akaike and Yamada found that polyphenol content and quality grades ran parallel, except when they were inversely related with rutin in cutter and leaf of bright yellow tobacco (4).

In a comprehensive review of phenolics presented at the 1976 Tobacco Chemists' Research Conference (Nashville, Tenn.), Kallianos reported that rutin and chlorogenic acid seem to correlate directly with flue-cured tobacco quality (26). Earlier, Arsenyan also reported positive correlations between those substances and tobacco quality $(7,8)$. He found that levels of both chlorogenic acid and rutin decreased with decreasing quality of Oriental leaf (8).

Phillips and Bacot found that lignin content increases in tobacco as the plant ages; very high concentrations often indicate over-ripeness (49). In the 1950's, Pyriki and others reported an inverse relationship between lignin content and tobacco quality $(49,56)$.

\section{Proteins}

Like many other substances, the effects of protein on tobacco quality are complex. In general, albumin and other proteins have a negative influence on tobacco quality, especially on taste. However, some protein content is needed for full taste, taste strength, and a degree 
of bitterness $(1,66)$, and, in fact, Grob asserts that soluble proteins are a common determinant of quality (22).

Proteins impart an unpleasant odor when burning, though small amounts have been shown to have a positive effect on aroma $(1,66)$. Amino acids are precursors of aroma (1) and are thought to contribute to smoke flavor (2). In flue-cured tobacco at least, two amino acids, alanine and glutamine, may directly correlate with smoking quality as indicated by a high negative correlation coefficient. Leffingroell also reports that proline content is high in quality flue-cured tobacco (31).

Protein content is high in Burley tobacco, low in fluecured, and in-between in Oriental (1).

\section{Volatile Bases}

In general, volatile bases influence only flue-cured tobacco quality (15) by contributing to flavor (2) and indicating body or strength (66).

Shmuk states that ammonia is a very important negative indicator of tobacco quality (66). Although some ammonia content is necessary to provide sensation, ammonia does promote harshness and is a negative factor in general (1).

\section{Volatile Oils}

Volatile oils have a positive influence on quality and contribute to flavor and aroma $(1,66)$.

\section{Waxes, Lipids, and Terpenes}

Waxes and lipids constitute a large and important group of substances found in tobacco leaf and smoke. In his 1976 paper, Davis (13) stressed the importance of the pyrolytic products of waxes and lipids in determining smoke quality, and aroma. Isoprene-derived lipids, especially ionones and related compounds, which are the degradation products of carotenoids, do seem to affect quality. While Phillips and Bacot, in a 1953 study, found no direct relation between waxes and tobacco quality (49), Davis more recently reported that both waxes and lipids seemed to contribute directly to smoke aroma and quality (13), and Pyriki emphasized the role of waxes and resins in reducing sharp tastes in smoke (54).

Phillips' and Bacot's 1953 report accented the role of resins in determining the amount of aroma produced, but found no direct relationship between resin content and aroma quality (49). However, most sources indicate that resins and their pyrolytic degradation products are positively correlated with quality, aroma and taste $(1,5$, $28,35,54,56,66)$. In Iraqi tobacco, an average resin content is best in terms of quality (20).
Both Davis and Abdallab report that esters of phytosterol and esters of solanesol have slightly negative influences on aroma $(1,13)$. According to Davis, neither phytosterol nor solanesol seems to affect quality, though solanesol may contribute to diterpenes in smoke and thereby influence smoke aroma indirectly. Duvatrienediol, a diterpene, has not been associated positively with smoke flavor or aroma (13).

Davis also asserts that paraffin hydrocarbons have no direct relationship with leaf quality, though some reports indicate they have a negative effect on smoke flavor and aroma $(1,13)$. Soluble hydrocarbons have been positively correlated with quality (68). An unsaturated hydrocarbon, neophytadiene, reportedly may enhance aroma and taste and contribute to quality, but no conclusive evidence has been presented thus far (13).

Davis' 1976 paper (13) provides a thoroughly comprehensive review of the role of waxes and lipids in determining smoking quality and aroma.

Table 1 attempts to summarize those components of tobacco which generally have a direct relationship to quality, those which generally have an inverse relationship to quality, and those for which no definitive conclusions have been reached as far as their role in determining tobacco quality is concerned. The numbers denote the references which have reported on these relationships.

\section{INDICES QUANTIFYING TOBACCO QUALITY}

Because the relationship between the many components of tobacco and tobacco quality is so complex, numerous researchers have attempted to devise formulas to relate various combinations of important substances to tobacco quality. Many of these involve the ratio of the sum of quality-producing substances to the sum of quality-inhibiting substances. However, it is difficult to apply these indices uniformly to tobaccos of different types or regions. In a study of some chemical quality indices, Ramakrisbnaya et al. (58) state that indices should only be used to compare tobacco grown under identical conditions of soil, climate and production practice, as these factors affect chemical composition.

Nevertheless, many researchers have continued to try to develop workable quality indices (see Summary Table 2). The three foremost were developed by Brückner, Pyriki, and Shmuk.

Brückner, in 1936, proposed using the ratio between the sum of quality-promoting substances multiplied by four hundred and the sum of quality-restricting substances. Thus he added together sugar, starch, oxalic acid, tannins, and resins, multiplied them by four hundred, and divided them by the sum of cell membrane substances plus ash plus citric acid plus nitrogenous compounds plus $\mathrm{pH}$ value (10):

(sugar + starch + oxalic acid + tannins + resins) $\times 400$ cell membrane substances + ash + citric acid + nitrogenous compounds $+\mathrm{pH}$ value 
In 1958, Pyriki (1) published his quality index which was derived from the sum of total reducing substances plus resins plus waxes, multiplied by four hundred and divided by the sum of ash, nicotine, protein, ammonia and residual nitrogen:

(total reducing substances + resins + waxes) $\times 400$. ash + nicotine + protein + ammonia + residual $N$

Sbmuk's quality index, published in 1953, consisted of the ratio between soluble carbohydrates and proteins. In his monumental work on the chemistry and technology of tobacco (1), he discusses several other equations which may relate to tobacco quality. A high nicotine number, which is derived from dividing the percentage of total nicotine by the percentage of free nicotine, indicates high quality. Likewise, a high nitrogen number, the quotient of nicotine nitrogen over ammonia nitrogen, indicates high quality. The polyphenol number, which compares the percentage of polyphenolic substances expressed in terms of glucose to the total quantity of reducing sugars, gets higher as tobacco quality gets lower (66).

In a paper published in 1961, Pyriki (52) discusses several other attempts to develop quality indices for tobacco. He states: "The quality numbers which have been achieved long ago and which are the basis of tobacco analysis resemble each other fundamentally because they are based on the determination of more or fewer tobacco content substances which are compared according to their quality promoting or quality-decreasing influence". Pyriki mentions that "the quality number of Molinari and Kuhn which was proposed a few years ago, as well as the quite recently made public quality number of $A k s u$ and Enercan both depend on the same basis. The latter is supposed to be valid for Turkish tobaccos of the Aegean district". Pyriki also cites the work of Trifu, who proposed that tobacco quality could be determined by comparing the ratio between the total reducing substances of smoke and the total nitrogen of smoke. Pyriki reports that Bodnar and Votiszky suggested a "smoke number" based on the microdetermination of tobacco smoke alkalinity according to Nagy. Jeney and Nemeth also developed a similar "smoke number". Shmuk number, Pyriki number, Molinari and Kubn number, and Trifu number all decrease as tobacco quality decreases. The Jeney and Nemeth number increases as tobacco quality declines (52).

In 1971, Sanaullab (61) briefly reviewed early work in the area of tobacco quality. He cites Reiser's 1937 "qualitative value”, the Shmuk number, Pyriki's work on relative quality, Dezelic's 1949 coefficients for mildness percentage, polyphenol number and harmonic value. Sanaullah also mentions the commercial quality index developed in 1961 by Aksu and Enercan as well as Dzhalal Shafik's 1965 index of physiological strength. For Oriental tobacco, Sanaullab uses the $\mathrm{pH}$ value as an index to quality, with a low $\mathrm{pH}$ indicating better quality (61).

A study on Spanish tobaccos found that the ratio of $\mathrm{CaO}$ to $\mathrm{K}_{2} \mathrm{O}$ was "near 1 for good tobaccos. The time of burning was in direct proportion to the quotient $\mathrm{K}_{2} \mathrm{O} / \mathrm{Cl}$; for good tobaccos it is $>5$, for passable 3-4, and for poor $<3$ (64).

Rodriguez (59) presents a tentative index for determining the quality of Cuban tobaccos, i, e.

for alkaline tobacco:

$$
\frac{(\text { nicotine } \times 100)+\text { (resins }+ \text { waxes }) \times 10}{\text { total } N-\text { nicotine } N},
$$

for acidic tobacco:

$$
\frac{\text { sugars }+ \text { nicotine }+ \text { (resins }+ \text { waxes }) \times 10}{\text { total } N} .
$$

Chakraborty and Kameswara (11) discuss the importance of the sugar/nicotine balance in determining tobacco quality. Murty et al. (39) also examine the ratio of reducing sugars to nicotine, reducing sugars to total nitrogen, and reducing sugars to protein as indices of tobacco quality.

Table 2. Clessification of quality indlces with reference to

\begin{tabular}{|c|c|c|}
\hline \multirow[b]{2}{*}{ Index } & \multicolumn{2}{|c|}{ Classification derived from } \\
\hline & $\begin{array}{l}\text { tobacco } \\
\text { constituents }\end{array}$ & $\begin{array}{c}\text { smoke } \\
\text { composition }\end{array}$ \\
\hline Ahmad & & $x$ \\
\hline Aksu \& Enercan & Turkish & \\
\hline Araiba & $x$ & \\
\hline Bodnar \& Votlszky & & $x$ \\
\hline Brockner & $x$ & \\
\hline Chakraborty \& Kameswara & $x$ & \\
\hline Dezelic & $\times$ & \\
\hline Fujiwara \& Kurosawa & $x$ & \\
\hline Gopalakrishna & Burley & \\
\hline Harlan \& Moseley & & $\times$ \\
\hline Jeney \& Nemeth & & $\times$ \\
\hline Kovalenko & Flue-cured & \\
\hline Mokhnachev et al. & $\mathbf{x}$ & $x$ \\
\hline Molinari \& Kuhn & $x$ & \\
\hline Muramatsu et al. & $x$ & \\
\hline Murty & $x$ & \\
\hline Obl & $\begin{array}{c}\text { Flue-cured, } \\
\text { Japanese, Burley }\end{array}$ & Flue-cured \\
\hline Pyriki & $\mathbf{x}$ & \\
\hline Reiser & $x$ & \\
\hline Rodriguez & Cuban & \\
\hline Sanaullah & Oriental & \\
\hline Sabir & $x$ & \\
\hline Shmuk & Flue-cured & \\
\hline Trifu & & $x$ \\
\hline
\end{tabular}
tobacco or smoke composition. 
Abmad (3) states that the "nitrogen-nicotine-sugar balance, in general, regulates the smoke quality of tobacco".

Obi et al. (40) have worked on several possible avenues for evaluating tobacco quality from its chemical constituents. They compared the products of the pyrolytic degradation of sugars and resins $(F)$ to the products of the pyrolytic degradation of cellulose $(E)$, and reported: "The general consideration of the F/E value in connection with several properties of tobacco leaves supported the following possibilities for the quality index of tobacco leaves: index of the combustibility of tobacco leaves and tar content in smoke, index of aroma and (or) taste and (or) strength of flue-cured tobacco leaves, and index of harshness or irritation of Japanese domestic and Burley tobacco leaves".

Obi et al. (41 to 45) discuss the relationship between ${ }^{\alpha} \mathrm{K}$ value $(\mathrm{K}=100 \mathrm{~F} / \mathrm{E}$ ) (see preceding paragraph for $\mathrm{E}$ and $\mathrm{F}$ values) and smoke aroma and taste as follows:

For aroma and/or taste at a confidence coefficient of 95 percent:

$$
\begin{aligned}
& Y_{1}=0.068 X-2.65 \pm 0.3, \\
& \text { where } \\
& Y_{1}=\text { aroma and/or taste, } \\
& X=\mathrm{X} \text { value. }
\end{aligned}
$$

For aroma plus taste at a confidence coefficient of 95 percent:

$$
Y_{2}=0.128 X-4.34 \pm 0.33 \text {, }
$$

where

$\mathrm{Y}_{2}=$ aroma plus taste,

$\mathrm{X}=\mathrm{K}$ value,

or, at a confidence level of 95 percent:

$$
\begin{aligned}
\mathrm{Y}=0.068 \mathrm{X}-2.65 \pm 0.30(75<\mathrm{X}<156) \\
\text { where } \\
\mathrm{Y}=2.0-2.5(\mathrm{X} \leq 75) \\
\mathrm{Y}=8.0-8.5(\mathrm{X} \geq 156) \\
\mathrm{Y}=\text { aroma and/or taste, } \\
\mathrm{X}=\mathrm{K} \text { value. }
\end{aligned}
$$

They further (45) refined their equations to derive the Ku value * which "was established as a new coefficient for the evaluation of smoking quality of flue-cured tobacco leaves as follows":

KM value -

$$
\frac{\text { (isoprene }+2) \times(2,5 \text {-dimethylfuran })}{\text { (acetaldehyde }+ \text { acetone }+ \text { acrolein }) \times 100}
$$

In another study by Muramatsu, Obi, Shimada and Sakurai (35), dryness was postulated as an indicator of tobacco quality. Dryness, or D value, was computed from the ratio of isoprene plus the products of the pyrolytic degradation of resinous substances to 2-methylfuran plus 2,5-dimethylfuran.

Muramatsu et al. $(36,37)$ also report on two additional quality coefficients, i.e. KPA, "based on the pyrogram of powdered tobacco, obtained with a fixed pyrolytic temperature $\left(550^{\circ} \mathrm{C}\right)$ and time $(15 \mathrm{~s})^{\boldsymbol{0}}$ and $\mathrm{K}_{\mathrm{PN}}$, "based on the pyrogram of powdered tobacco leaves in $\mathrm{N}$.

Mokbnachev and Kamenshchikova (33) developed the elaborate equations below to determine the relationship between tobacco constituents and flavor as well as between smoke constituents and flavor. However the calculated data and the real data may vary as much as $\pm 20 \%$.

\section{Constituents of tobacco in relation to:}

Flavor $=$

0.064 resins $^{+}-0.013$ carbohydrates +0.017 proteins +0.017 water soluble substances + 0.009 alcohol soluble substances +0.008 substances of acid nature in aqueous tobacco extract -0.014 nicotine +0.0002 alkaline substances in aqueous extract -0.303 carbonyl compounds (non-carbohydrate) in aqueous extract +0.109 methanol in aqueous extract.

Taste $=$

0.060 resins -0.009 carbohydrates +0.020 proteins +0.016 water solubles +0.007 alcohol solubles +0.008 acidic substances in aqueous extract -0.009 nicotine +0.001 alkaline substances in aqueous extract -0.227 carbonyl compounds (non-carbohydrate), in aqueous extract +0.095 methanol in aqueous extract.

\section{Constituents of smoke in relation to:}

Flavor $=$

-0.0096 wet condensate ${ }^{++}+0.1844$ volatile acids +0.1667 nicotine +11.3409 volatile phenols +0.9866 methanol +0.1553 carbonyl compounds (non-carbohydrate).

\section{Taste $=$}

-0.0087 wet condensate +0.1944 volatile acids +0.1490 nicotine +10.9868 volatile phenols +0.9796 methanol +0.1532 carbonyl compounds (non-carbohydrate).

The Kovalenko coefficient, which was developed in 1935, compares the percentage of reducing sugars, expressed as glucose, to the percentage of total nitrogen (49).

\footnotetext{
$+\mathrm{mg} / \mathrm{g}$ of absolute dry tobacco

$++\mathrm{mg} / \mathrm{g}$ absolute $d r y$ burnt tobacco
} 
Fujiwara and Kurosawa (17) report that: "The ratio of reducing sugar to total $\mathrm{N}$ gave a better indication of quality than the Shmuk quotient ...* .

In a study of some chemical quality indices, Ramakrishnayya et al. (58) found "good agreement among the Shmuk numbers, Kovalenko coefficients, and the grade of tobacco".

However, as Gopalakrishna at al. (21) point out in their 1977 paper, both the Shmuk number and Kovalenko coefficient were developed using flue-cured tobacco. In their paper, they attempt to develop a quality index for Burley tobacco and conclude: "The correlation coefficient of protein $\mathrm{N}$ to quality was found to be -0.5621 and this appears to be suitable as an index of quality of Burley tobacco".

Sabir (60) cites the ratio of protein $N$ (multiplied by one hundred) to total $\mathrm{N}$ as an index of tobacco quality.

Harlan and Moseley (34) state that "the ratio of nicotine to total volatile bases is particularly useful as an index of the palatability of smoke".

Finally, Araiba et al. (6), as mentioned earlier, feel that the iron to manganese ratio may be another indicator of tobacco quality.

Obviously, there is a plethora of indices referenced in the published literature. It is assumed, however, that research groups either apply these selectively or integrate them partially with their own formulas for analyzing tobacco. These "formulas" are considered trade secrets, for the most part. But it is likely that they examine balances of constituents similar to those described above.

Table 2 represents an attempt to classify various quality formulas based on whether they were derived from looking at tobacco constituents or smoke composition.

\section{CONCLUSIONS}

Of the many considerations involved in quality evaluation, ultimate judgments seem to have relied on subjective assessments of smoke aroma and taste. This subjective aspect, applied to widely varying types of tobacco, combined with a general vagueness as to the meaning of the term "quality" itself, renders a survey of research in the area of tobacco quality necessarily inconclusive. Nevertheless, it should be useful as a review of work performed in the field from the mid-1930's to the late 1970's.

\section{BIBLIOGRAPHY}

These items, in conjunction with those listed under References, constitute a rather comprehensive bibliography of work published between 1936 and 1979 which deals with the relationship between the chemical constituents of tobacco and smoke and tobacco and smoke quality. As they have not been referenced in the text of this review, they appear separately here.

Andersen, R. A., T. C. Tso and J. F. Chaplin: Total carbonyls and phenols in experimental Burley and Bright tobacco; Agric. Food Chem. 27 (1979) 891 895.

Anitia, N.: The influence of soil humidity on the production and quality of tobacco; Rev. Int. Tab. 24 (1949) 133-136.

Arany, S.: Role of nitrogen containing material of tobacco and its effect on quality; Dohányipar 1973, 3, 95-101.

Atanasov, B.: Chemical composition and smoking properties of artificially dried Oriental tobacco; Bulg. Tiutiun 22 (1977) 21-28.

Aversano, B., M. Abet and R. Contillo: Chemical composition of Burley tobacco and its significance to quality (preliminary note); Ann. Ist. Sper. Tab. 4 (1977) 209-221.

Baets, A. de: Do dithiocarbamates influence the quality of the treated tobacco?; Med. Land. Opzock. Staat Gent 27 (1962) 1148-1163.

Bonazzi, A.: Physiology of tobacco, V. Relation between the soil and the industrial quality of golden tobacco in cultivation; Acta Cient. Venez. 3 (1952) 14-22.

Boneva, A.: Effect of chemical composition on burning qualities of Oriental tobacco; Bulg. Tiutiun 22 (1977) 30-33.

Borbolla y Alcala, J. M. R., and A. D. C. Brsezicki: A synthetic technique for the chemical study of the burning quality of tobacco (Ministerio Agr., Inst. Nacl. Invest. Agron., Centro Estud. Tabaco); Santiponce No. 94, 1947, 257-288.

Buchinskii, A. F.: Leading factors in forming the type and quality of tobacco raw materials; Tabak (Mosc.) 1974, 3, 36-39.

Budorov, D.: Correlation between the external characteristics of tobacco leaves and their chemical composition and smoking properties; Bulg. Tiutiun 6 (1961) 39-44.

Card, D. G., and W. H. Minton: An index of general quality of Burley tobacco - Grading; Kentucky Agricultural Experiment Station, Louisville, Kentucky, 1974.

Collins, W. K., G. L. Jones and W. W. Bates: Performance of flue-cured tobacco varieties for certain nitrogenous constituents and reducing sugars; Tob. Sci. 9 (1965) 38-43.

Constantinescu, T.: Possible contribution of sugars, amino acids and polyphenols to the formation of tobacco aroma and color; Ind. Aliment. 24 (1973) 136-139. 
Court, W. A.: Importance of chemistry in quality evaluation; Lighter 46 (1976) 5-7.

Csongradi, M.: Comparison of new and old methods of quality-index forming; Dohányipar 1974, 21, 37-40.

Delac, I., N. Vuletic and F. Prpic: Chemical composition and qualitative characteristics of different varieties of Burley produced in Yugoslavia in 1972; Tutun 23 (1973) 213-220.

Demeczky, M.: Determination of the smoking value of tobaccos and tobacco products; Proc. 2nd Int. Sci. Tob. Congr., Brussels, 1958, 545-549.

Enzell, C. R.: Terpenoid components of leaf and their relationship to smoking quality and aroma; Recent Adv. Tob. Sci. 2 (1976) 32-60.

Fardy, A.: Ontogenesis and the differentiation of various technological properties of tobacco leaves; Proc. 1st Int. Sci. Tob. Congr., Paris, 1955, 732-735.

Ferguson, T. P.: Studies in the growing of flue-cured tobacco, II. Some preliminary observations on the influence of temperature and light on the growth and quality of tobacco; Tob. Sci. 4 (1960) 159-162.

Furusawa, M., X. Masuo, K. Saitō, T. Hirose, K. Tsuzuki, Y. Katayama, F. Miyanowaki, M. Shinozaki and I. Abe: Studies on element of quality of leaf tobacco, II. The appraising element of flue-cured leaves (2); Jpn. Monop. Corp. Cent. Res. Inst. Sci Pap. 113 (1971) 59-69.

Garabedian, H:: Qualitative constituents of Baragan 226 variety tobacco; Ind. Aliment. 22 (1971) 155-157.

Gopalachari, N. C., and C. Sriramamurty: Chemical composition and quality of tobacco cured by infrared rays; Sci. Cult. 32 (1966) 151-153.

Gopalachari, N. C.: Prospects for improvement of quality in Indian flue-cured tobacco; Indian Tob. Bull. 3 (1971) 9-11.

Griest, W. H., and M. R. Guerin: Influence of tobacco type on smoke composition; Recent Adv. Tob. Sci. 3 (1977) 121-144.

Grimaldi, A.: Availability of potassium in the soil and quality of tobacco; Potassium Symposium, Rome, $1955,439-453$.

Grob, K.: Analytical determination of the quality of tobacco in Switzerland; Coresta Information Bulletin 1961-1, 89-91.

Gyuzelev, L.: Quality standards for the evaluation of the principal smoking characteristics of Bulgarian tobacco; Bulg. Tiutiun 6 (1961) 33-43.

Hamashima, T.: Aroma and taste of leaf tobacco and neutral constituents in the essential oil; Okayama Jpn. Tob. Exp. Stn. Bull. 39, 1978, 43-49.
Kaburaki, Y., C. Tokura, Y. Furukawa and M. Shiga: American and Canadian Burley tobacco leaves, III. Components of cigaret smoke; Jpn. Monop. Corp. Cent. Res. Inst. Sci. Pap. 107 (1965) 257-262.

Kamenshchikova, S. V., A. M. Smirnov and I. G. Mokhnachev: Spectrophotometric methods for the determination of tobacco quality; Tabak (Mosc.) 1975, 3, 36-39.

Kameswararao, B. V., B. V. Ramakrishnayya and A. S. Sastry: Effect of chlorides on the yield and quality of Indian flue-cured tobacco; Indian J. Agric. Sci. 34 (1964) 78-86.

Kevanishvili, V. N., L. M. Moistsrapishvili and I. A. Gabuniya: Relation among the content of organic acids, nicotine, ash, and electrical conductivity of aqueous extracts of tobacco; Tabak (Mosc.) 1969, 1, 55.

Laszlo, N.: Classification and judging the quality of cigarets and tobaccos according to the smoke; Dohányipar 1959, 134-137.

Len, S. C., and L. H. Teck: Effect of sugar content on quality of commercially cured Virginia leaf tobacco; Malays. Agric. Res. 3 (1974) 258-262.

Llanos Company, M.: Tobacco quality; Chacra (Peru) 1968, 21, 33-36, 43.

Macnicol, P. K., and P. M. Thorne: Fluorescent phenols as possible indexes of tobacco quality; Phytochem. 8 (1969) 689-696.

Marquez Jimenez, S.: Relation of potassium content to tobacco quality; An. Inst. Nac. Invest. Agrar., Ser. Tecnol. Agrar. 4 (1977) 149-166.

Massamtini, F., P. Pasquali and F. Caporali: Nitrogen fertilization of tobacco, Effect on yield, quality characteristics, and nicotine content; Agric. Ital. (Pisa) 69 (1969) 222-241.

Mokhnachev, I., L. Serdyuk and N. Ivanov: Free fatty monobasic acids in the smoke of Bulgarian Oriental tobaccos; C. R. Acad. Bulg. Sci. 20 (1967) 445-447.

Mokhnachev, I. G., L. A. Dulan and A. M. Smirnov: Mass spectrometry of tobacco materials; VINIrI, Moscow, 1976.

Mokhnachev, I. G.: Objective evaluation of the quality of tobacco of new varieties; Tabak (Mosc.) 1978, 3, 43-46.

Molinari, E., and H. Kuhn: Die chemische Qualitätsbestimmung des Tabaks als Hilfsmittel der Expertise (Analysis of quality); Fachl. Mitt. Osterr. Tabakregie 1954, No. 1, 1-9.

Morishita, I.: Tobacco flavor; Koryo 1959, 52, 11-19.

Müller, R., W. Moldenhauer and M. Richter: Öber die chemische Zusammensetzung von Orient- und Virginiatabaken; Ber. Inst. Tabakforsch. Dresden 16 (1969) 45-58. 
Mulchi, C. L.: Development of an index of quality for Maryland tobacco; Maryland Agr. Exp. Sta., Beltsville, Maryland, 1977.

Munchenbach, G.: La dégustation des tabacs - êléments pour l'élaboration d'une méthode d'analyse des perceptions sensorielles; Service d'Exploitation Industrielle des Tabacs et Allumettes, Paris, 1969.

Murty, K. S. N., N. C. Gopalachari, M. Subramanyan, P. R. Ramachander and A. S. Sastry: Interrelationship of physical and chemical attributes in FCV tobacco; Tob. Res. 2 (1976) 45-51.

Narasimhayya, G., and N. C. Gopalachari: Chemical quality indices and physical appraisal in relation to price of flue-cured tobacco; Indian Tob. Bull. 4 (1972) 13-20.

Nel, J. G., J. H. Swanepoel and C. W. Glennie: Some physical and chemical properties of flue-cured tobacco and their relation to grade; Agrochemophysica 7 (1975) 9-14.

Nestorov, A.: One more opinion about the effect of soluble carbohydrates and protein matter on the smoking qualities of tobacco; Bulg. Tiutiun 24 (1979) 24-27.

Nikolova, M.: Polonium-210 content in tobacco leaves in relation to their quality (class); Roentgenol. Radiol. 14 (1975) 119-123.

Obi, Y., Y. Shimada, M. Muramatsu and H. Sakurai: Evaluation of tobacco quality from pyrolytic aspects, VI. Differential thermal analysis (DTA) patterns of leaf tobaccos; Jpn. Monop. Corp. Cent. Res. Inst. Sci. Pap. 111 (1969) 129-134.

Obi, Y., M. Muramatsu and Y. Shimada: Evaluation of tobacco quality from pyrolytic aspects, VII. Relationship between chemical constituents of tobacco leaves and gaseous constituents of cigarette smoke; Agric. Biol. Chem. 34 (1970) 1220-1223.

Onishi, I., M. Izawa and H. Sakurai: The effects of moistening under reduced pressure on the qualities of tobaccos; Jpn. Monop. Corp. Cent. Res. Inst. Sci. Pap. 86 (1955) 57.

Oy, A. T: Improving tobacco quality; Patent No. 34927, Finland, 1966.

Panin, V. A., and S. A. Ukhanova: Quality certification of products in the branch of tobacco industry; Tabak (Mosc.) 1975, 2, 33-36.

Pawlowska, A.: Studies on polyphenols in tobacco, 1. Trials to determine the effects of polyphenols on tobacco flavour characteristics; Biul. Central. Labor. Przem. Tyton. 1/2 (1973) 71-81.

Prikhod'ko, M. S.: The effect of azotobacterin and of phosphobacterin on the yield and quality of tobacco; Sb. Nauchno-Issled. Rab. Vses. Nauchno-Issled. Inst. Tab. Makhorki 1958, 150, 148-159.
Pruidze, V. G., and M. I. Geleishvili: Qualitative composition of amino acids in tobacco; Tr. Gruz. Nauchno-Issled. Inst. Pishch. Prom. 2 (1966) 289-293.

Pyriki, C., and W. Philipp: Der Einfluß verschiedener anorganischer Salze auf die Glimmfähigkeit des fermentierten Tabaks; Ber. Inst. Tabakforsch. Dresden 2 (1955) 94-111.

Pyriki, C, and R. Herrmann: Die organischen Säuren in den Blattgutarten des Tabaks und deren Beziehungen zur Qualität; Ber. Inst. Tabakforsch. Dresden 4 (1957) 285-307.

Rice, J. C., T. R. Terrill, R. Currin, R. Golden and F. Clark: Quality determination in flue-cured tobacco as evaluated by the minimum standards program; North Carolina State University, Raleigh, N. C., 1972-73.

Sabourin, L.: Tobacco quality and combustibility as affected by its chlorine content, $I$. The industrial defects of high chlorine tobaccos; Coresta Information Bulletin 1967-2, 14-16.

Schmid, K.: Verbesserung der Brandeigenschaften des Tabaks durch Beachtung des Kalk-Kalifaktors bei der Düngung; Tabak-Forschung, Organ des Tabakforschungsinstituts Forchheim bei Karlsruhe, Wissenschaftliche Beilage der Süddeutschen Tabakzeitung, Mainz, Jahrgang 1949 (Nr. 2), 5-8.

Schmid, K.: Nicotine content and quality of tobacco; Proc. 2nd Int. Sci. Tob. Congr., Brussels, 1958, 305-322.

Senn, T. L., R. B. Griffith, C. L. Ogg and R. T. Pernell: Alkaloid studies of acceptable and discount varieties of flue-cured tobacco grown in 1957; U.S. Dept. Agr. Rep. ARS 73-24, Washington, D.C., 1961.

Shafik, J.: Quality of Iraqi tobaccos based on some physicochemical properties; Indian J. Agr. Sci. 44 (1974) 27-31.

Shakhnovskii, L. N.: Chemical composition of tobacco smoke; Tabak (Mosc.) 1960, 4, 17-20.

Shakhnovskii, L. N.: Hydrolyzed nicotine as indicator of the smoking quality of Makhorka; Tabak (Mosc.) 1958, 1, 14-17.

Shapovalov, E. N.: Terminology of tobacco raw material quality; Tabak (Mosc.) 1976, 2, 42-43.

Shimada, Y., M. Muramatsu and Y. Obi: Evaluation of tobacco quality from pyrolytic aspects, XI. A new index of incineration process of tobacco leaves by differential thermal analysis; Jpn. Monop. Corp. Cent. Res. Inst. Sci. Pap. 113 (1971) 77-81.

Shimada, Y., M. Muramatsu, Y. Obi and T. Fukuzumi: Evaluation of tobacco quality from pyrolytic aspects, $\mathrm{XV}$. The coordinate from the indices characteristic of differential thermal analysis of tobacco leaves; Jpn. Monop. Corp. Cent. Res. Inst. Sci. Pap. 114 (1972) 223-226. 
Skiba, G. M.: Elaboration of a new standard for tobacco raw materials quality; Tabak (Mosc.) 1974, 3, 29-34.

Smirnov, A. M., and I. G. Mokhnachev: Organoleptic properties and chemical composition of tobacco; Tabak (Mosc.) 1973, 2, 42-43.

Stakjov, P.: Quality requirements of the international market for Virginia tobacco from Bulgaria; Bulg. Tiutiun 8 (1979) 37-39.

Stedman, R. L., D. Burdick, W. J. Chamberlain and I. Schmeltz: Composition studies on tobacco, XVIII. Steam-volatile acids in smoke of cigarettes having different organoleptic properties; Tob. Sci. 8 (1964) 79-81.

Sugawara, S., U. Kobashi and H. Sakurai: Chemical evaluation of tobacco quality, I. Possibility for the evaluation of tobacco quality from chemical composition in particulate phase of the cigaret smoke; Agric. Biol. Chem. 35 (1971) 596-603.

Sugawara, $S_{-2}, U$. Kobashi and $H$. Sakuraj: Studies on the chemical evaluation of tobacco quality, III. Evaluation of tobacco quality from gas chromatographic analysis of particulate phase of the cigarette smoke; Tob. Sci. 16 (1972) 95-97.

Sugawara, S., U. Kobashi and H. Sakurai: Studies on the chemical evaluation of tobacco quality, IV. Possibility for the evaluation of the quality of Burley tobacco from gas chromatographic analysis of particulate matter of smoke; Jpn. Monop. Corp. Cent. Res. Inst. Sci. Pap. 114 (1972) 227-229.

Sugawara, S., U. Kobashi and H. Sakurai: Studies on the chemical evaluation of tobacco quality, Organoleptic and gas chromatographic evaluation of the differences with respect to the growth district and stalk position of flue-cured tobacco; Jpn. Monop. Corp. Cent. Res. Inst. Sci. Pap. 112 (1970) 143-148.

Szilagyi, J.: New quality index of tobacco products; Dohányipar 1972, 19, 207-212.

Tabakova, E.: Expert grading of tobacco by external quality indices; Bulg. Tiutiun 24 (1979) 42-46.

Takahara, H., T. Shinkai, H. Inumaru and I. Morishita: Studies on tobacco extract, II. The improvement of smoking taste of $A$ and $B$ fractions by chemical treatments; Jpn. Monop. Corp. Cent. Res. Inst. Sci. Pap. 109 (1967) 87-91.

Tanaka, S., and S. Jimbo: Ecological studies on characters of leaf tobacco with respect to chemical composition, III. Analysis of smoking values by the chemical composition; Hatano Jpn. Tob. Exp. Sta. Bull. 1973, 73, 161-174.

Tanaka, S., and H. Ishii: Statistical analysis of relations between quality and composition of leaf tobacco, II. Statistical analysis of Burley tobacco; Hatano Jpn. Tob. Exp. Sta. Bull. 1969, 64, 1-58.
Teslinova, I. G.: Increasing the role of standards in raising the quality of tobacco products; Tabak (Mosc.) 1975, 3, 14-16.

Tinchev, T., E. Yazydzhiyan and K. Paskaleva: Chemical composition and flavor quality of some air-cured large tobacco leaves; Nauchno-Issled. Inst. Tiutiuneva Prom. Plovdiv. Nauchn. Tr. 1 (1967) 183-189.

Toyoda, I., J. Kobata, Y. Akinaga, T. Shinohara, I. Kanai, S. Tabe, T. Itaishi, Y. Hiroyasu and A. Kato: Redrying and aging of tobacco leaves, IV. Aging of the Japanese bright yellow tobacco leaves; Jpn. Monop. Corp. Cent. Res. Inst. Sci. Pap. 96 (1956) 1.

Trifu, I.: Determination of the quality of tobacco by chemical analysis of the tobacco smoke; Lucrarile Inst. Cercetari Aliment. 1 (1957) 145-162.

Tyrer, D., and D. D. Tyrer: Improving the smoking qualities of tobacco; Patent No. 2,914,072, United States, 1959.

Vanbercie, R.: Evaluation of the quality of tobaccos; Agron. Trop. 19 (1964) 598-607.

Veitsler, V. G.: Isolation of a group of alcohols from tobacco aromatics and their effect on quality; Khim. Tekhnol. (Krasnodar) 2 (1973) 136-137.

Wagner, K. G.: Uber einige Zusammenhänge zwischen organoleptischem und analytischem Befund bei Nahrungsmitteln; $Z$. Lebensm.-Unters. u. -Forsch. 89 (1949) $241-250$.

White, F. H., R. S. Pandeya and V. A. Dirks: Correlation studies among and between agronomic, chemical, physical and smoke characteristics in flue-cured tobacco; Can. J. Plant Sci. 59 (1979) 111-120.

Yamazaki, M., M. Uehara, M. Shigematsu, K. Asõ, T. Odaka and Y. Kuwahara: Variation of chemical composition of the tobacco leaves for quality examinationyears and habitats of crop; Jpn. Monop. Corp. Cent. Res. Inst. Sci. Pap. 112 (1970) 35-50.

Zheliazkov, D., and A. Tomov: Investigation on quality of reconstituted tobacco; Inst. Tiutiuna Tiut. Izdel., Plovdiv. Nauchni Tr. 5 (1975) 163-173.

Zuykova, E. P., A. M. Smirnov and I. G. Mokhnachev: Commercial quality of tobacco and its chemical composition; Tabak (Mosc.) 1973, 1, 41-44.

Zuykova, E. P., I. I. Baskin and A. A. Stepanenko: Organoleptic and physicochemical qualities of Kirghizia tobacco; Tabak (Mosc.) 1969, 4, 35-38.

\section{REFERENCES}

1. Abdallah, F.: Can tobacco quality be measured?; Lockwood Publishing Co., Inc., New York, N. Y., 1970. 
2. Abdallah, F.: Sensory testing of cigarette smoke, Panel selection, training, and use; $\mathrm{Ph}$. D. dissertation, North Carolina State University, Raleigh, N. C., 1974.

3. Ahmad, M.: Quality of flue-cured tobacco in relation to agronomy; Pak. Tob. 1 (1977) 35-36.

4. Akaike, S., and S. Yamada: Chemical constituents of tobacco plant, IX. Contents of chlorogenic acid and rutin in flue-cured tobacco, their relation to quality, and the content variation with locality; Hatano Tab. Shik. Tok, Hokoku 1966, 57, 47-57.

5. Alic-Djemidzic, N.: Determination of resins in tobacco from Herzegovina and their effect on quality during smoking; Kem. Ind. 19 (1970) 391-399.

6. Araiba, $K$, and N. Honda: Studies on the contents of micrometal elements in flue-cured tobacco leaves, I. Survey of iron, manganese and zinc contents of flue-cured tobacco leaves (var. MC) from 1973 crops; Okayama Tabako Shikenjo Hokoku 1976, 36, 33-41.

7. Arsenyan, E.: Levels of chlorogenic acid and rutin in Oriental tobacco and their relation to tobacco quality; Dokl. Akad. Selskokhoz. Nauk Bolg. 1 (1968) 53-56.

8. Arsenyan, E.: Polyphenols, Relation to quality and changes in composition during different types of fermentation of Oriental tobaccos; Bulg. Tiutiun 13 (1968) 31-36.

9. Borbolla y Alcala, J. M. R., and V. C. Munoz: The synthetic method for the chemical study of the combustibility of tobacco, IV. Considerations on the influence of chlorine; Ion 10 (1950) 655-658.

10. Brũckner, H.: Die Biochemie des Tabaks und der Tabakverarbeitung; Verlagsbuchhandlung Paul Parey, Berlin, 1936.

11. Chakraborty, M. K, and R. B. Kameswara: Comparative evaluation of quality in flue-cured tobacco from India, Thailand and Brazil; Indian Tob. Bull. 8 (1977) 3-15.

12. Chenikov, V. V., and E. N. Shapovalov: Tar components of tobacco and the products of its burning; Izv. Vyssh. Uchebn. Zaved. Pishch. Tekhnol. 5 (1965) 65-69.

13. Davis, D. L.: Waxes and lipids in leaf and their relationship to smoking quality and aroma; Recent Adv. Tob. Sci. 2 (1976) 80-111.

14. D'yachkin, I. I., A. V. Burlakina and Z. P. Belyakova: Correlation of carbonyl compounds with aroma properties of unprocessed tobacco material; Sb. Nauchno-Issled. Rab. Vses. Nauchno-Issled. Inst. Tab. Makhorki 1971, 157, 137-142.

15. Egerer, A., and G. Löffler: Qualitätsuntersuchungen einheimischer Schneideguttabake; Ber. Inst. Tabakforsch. Dresden 23 (1976) 10-20.

16. Fujiwara, A., and M. Kurosawa: The biting taste of Burley tobacco leaves, I. Relation between the taste and the period of transplanting; J. Sci. Soil Manure (Japan) 23 (1952) 32-36.
17. Fujiwara, A., and M. Kurosawa: Biting taste of Burley tobacco leaves (nutritional physiology of Japanese tobacco), I. Relation between the biting taste and chemical components; Tohoku J. Agric. Res. 5 (1954) 229-237.

18. Fujiwara, A, and M. Kurosawa: Biting taste of Burley tobacco leaves (nutritive physiology of Burley tobacco), III. Effect of form and amount of supplied nitrogen and quality of Burley tobacco; J. Sci. Soil Manure (Japan) 26 (1955) 207-214.

19. Gartner, K.: Change of quality of artificially fermented tobaccos during storage; Magy. Kem. Lapja 2 (1947) 317-320, 343-350.

20. Georgiev, S., and H. A. Ibrahim: Study of the Iraqi tobaccos with regard to their use in the cigaret production, II. Chemical composition and smoking qualities of tobacco; Nauchn. Tr. Vissh. Inst. Khranit. Vkusova Prom-st. (Plovdiv) 22 (1975) 133-144.

21. Gopalakrishna, C. V. S. S. V., G. S. V. Subrahmanyam and A. S. Sastry: Evaluation of a suitable quality index for Burley tobacco grown in black soils of Andhra Pradesh; Tob. Res. 3 (1977) 59-61.

22. Grob, K.: Einige Erfahrungen mit der analytischen Qualitātsbestimmung an schweizerischem Inlandtabak; Beitr. Tabakforsch. 1 (1961) 15-18. .

23. Hsieh, R. H.: Studies on the chemical analyses of leaf quality of Taiwan tobacco, $I$. The relationship between new leaf grades and chemical constituents of tobacco leaves in Taiwan; Taiwan Tob. Wine Monop. Bur. Tob. Res. Inst. Bull. 3 (1975) 15-28.

24. Hsieh, R. H.: A study of the main chemical constituents of flue-cured tobacco produced in Taiwan; Taiwan Agric. Quarterly 9 (1973) 187-195.

25. Jeney, K., and L. Nemeth: The qualification of cigaret tobaccos on the basis of smoke investigations; Dohány. Intezet Kozlem. 1 (1958) 9-12.

26. Kallianos, A. G.: Phenolics and acids in leaf and their relationship to smoking quality and aroma; Recent Adv. Tob. Sci. 2 (1976) 61-79.

27. Kamenshchikova, S. V., and I. G. Mokhnachev: Formaldehyde in tobacco smoke; Tabak (Mosc.) 1973, 4, 38.

28. Kevanishvili, V. N., and L. M. Moistsrapishvili: Aroma and tarry substances of tobacco; Tr. Gruz. Nauchno-Issled. Inst. Pishch. Prom 4 (1971) 218-222.

29. Kevanishvili, V. N.: Aromatic substances in tobacco; Tabak (Mosc.) 1968, 2, 21-22.

30. Kusama, M., T. Tsugane, T. Kurosawa and T. Muranaga: Smoking quality and chemical composition of Japanese flue-cured tobacco classified by stalk position; Jpn. Monop. Corp. Cent. Res. Inst. Sci. Pap. 107 (1965) 331-333.

31. Leffingwell, J. C.: Nitrogen components of leaf and their relationship to smoking quality and aroma; Recent Adv. Tob. Sci. 2 (1976) 1-31. 
32. Mokhnachev, I. G., and S. V. Kamenshchikova: Carbonyl compounds in tobacco smoke and their effect on the aroma; Sb. Nauchno-Issled. Rab. Vses. Nauchno-Issled. Inst. Tab. Makhorki 1970, $155,48-52$.

33. Mokhnachev, I. G., and S. V. Kamenshchikova: Methods for the objective evaluation of the quality of tobacco; Tabak (Mosc.) 1971, 2, 36-40.

34. Moseley, J. M., W. R. Harlan and H. R. Hanmer: Burley tobacco - Relation of the nitrogenous fractions to smoking quality; Ind. Eng. Chem. 43 (1951) 2343-2347.

35. Muramatsu, M., Y. Obi, Y. Shimada and H. Sakurai: Evaluation of tobacco quality from pyrolytic aspects, VIII. Evaluation of "dryness" of cigarette smoke of flue-cured tobacco leaves; Jpn. Monop. Corp. Cent. Res. Inst. Sci. Pap. 112 (1970) 99-106.

36. Muramatsu, M., Y. Obi and Y. Shimada: Evaluation of tobacco quality from pyrolytic aspects, XIII. Pyrolytic gas chromatography of powdered tobacco (1); Jpn. Monop. Corp. Cent. Res. Inst. Sci. Pap. 114 (1972) 75-80.

37. Muramatsu, M., Y. Obi and Y. Shimada: Evaluation of tobacco quality from pyrolytic aspects, XIV. Pyrolytic gas chromatography of powdered tobacco (2); Jpn. Monop. Corp. Cent. Res. Inst. Sci. Pap. 114 (1972) 81-87.

38. Muranaga, T., M. Kusama, T. Tsugane and T. Kurosawa: Relation between chemical composition and smoking quality of Japanese flue-cured tobacco; Jpn. Monop. Corp. Cent. Res. Inst. Sci. Pap. 106 (1964) 295-297.

39. Murty, X. S. N., P. R. Ramachander and A. S. Sastry: Desirable limits of chemical parameters for quality appraisal in flue-cured Virginia tobacco; Indian Tob. Bull. 6 (1974) 3-7.

40. Obi, Y., M. Muramatsu, Y. Shimada and H. Sakurai: Evaluation of tobacco quality from pyrolytic studies, II. The possibility of the quality evaluation of tobacco leaves by some gas phase compounds of tobacco smoke; Jpn. Monop. Corp. Cent. Res. Inst. Sci. Pap. 110 (1968) 201-209.

41. Obi, Y., Y. Shimada, M. Muramatsu and H. Sakurai: Evaluation of tobacco quality from pyrolytic aspects, III. The possibility of the quality evaluation of tobacco leaves by differential thermal analysis of tobacco leaves; Jpn. Monop. Corp. Cent. Res. Inst. Sci. Pap. 110 (1968) 211-216.

42. Obi, Y., M. Muramatsu, Y. Shimada and H. Sakurai: Evaluation of tobacco quality from pyrolytic aspects, IV. Evaluation of organoleptic properties of smoke of flue-cured tobacco by $\mathrm{K}$ value; Jpn. Monop. Corp. Cent. Res. Inst. Sci. Pap. 111 (1969) 117-123.

43. Obi, Y., M. Muramatsu, Y. Shimada and H. Sakurai: Evaluation of tobacco quality from pyrolytic aspects, V. Statistical investigation of correlation between gaseous constituents of cigarette smoke from which $K$ value was computed and organolep- tic properties of tobacco smoke; Jpn. Monop. Corp. Cent. Res. Inst. Sci. Pap. 111 (1969) 125-128.

44. Obi, Y., M. Muramatsu, Y. Shimada and H. Sakurai: Evaluation of tobacco quality from pyrolytic aspects, IX. Establishment of approximate formulas for the evaluation of the aroma and taste of cigarette smoke of flue-cured tobacco leaves; Jpn. Monop. Corp. Cent. Res. Inst. Sci. Pap. 112 (1970) 107-111.

45. Obi, Y., M. Muramatsu and Y. Shimada: Evaluation of tobacco quality from pyrolytic aspects, XII. Establishment of a new quality coefficient (KM value) of tobacco leaves by the retrenchment of number of gaseous compounds from which $K$ value was computed; Jpn. Monop. Corp. Cent. Res. Inst. Sci. Pap. 113 (1971) 83-87.

46. Ogonowski, J. W., and L. Rudra: The yield, quality, and chemical composition of flue-cured Virginia tobacco at two locations in Zambia; East Afr. Agric. For. J. 1976, 41, 298-303.

47. Pecijareski, D., and M. Mirceski: Effects of the size of leaves on the quality of tobacco type Virginia (physicochemical) properties; Tutun 1978, 28, 173-184.

48. Peterson, L. A., and T. W. Tibbitts: Chemical composition of tobacco in relation to leaf burn and quality; Agron. J. 55 (1963) 114-116.

49. Phillips, M., and A. M. Bacot: The chemical composition of certain grades of type 11, American flue-cured tobacco; J. Assoc. Off. Agric. Chem. 36 (1953) 504-524.

50. Pyriki, C.: Ein Beitrag zu der chemischen Qualitătsbeurteilung von fermentierten Orienttabaken; Z. Lebensm.-Unters. u. -Forsch. 88 (1948) 404-407.

51. Pyriki, C., and W. F. Homann: Über Chinatabake, II. Mitteilung: Die weiteren Merkmale der Tabake und die Wechselbeziehungen zwischen der chemischen Zusammensetzung und der Handelsqualität; Ber. Inst. Tabakforsch. Dresden 6 (1959) 106-125.

52. Pyriki, C., and R. Müller: Gegenüberstellung von Methoden zur objektiven Qualitātsbeurteilung von Zigarettentabaken; Ber. Inst. Tabakforsch. Dresden 8 (1961) 73-86.

53. Pyriki, $C$., and $W$. Moldenhauer: Untersuchungen über Tabakpektine und deren Einfluß auf die Tabakqualität; Ber. Inst. Tabakforsch. Dresden 10 (1963) 238-263.

54. Pyriki, C., and F. Hofmann: Die Paraffinkohlenwasserstoffe des Tabaks; Ber. Inst. Tabakforsch. Dresden 10 (1963) 69-106.

55. Pyriki, C., and W. F. Homann: Die Qualitātsmerkmale der Tabake unter besonderer Berücksichtigung der Zigaretten-Tabake; Z. Lebensm.Unters. u. -Forsch. 97 (1953) 281-289. 
56. Pyriki, C.: Beziehungen zwischen der chemischen Zusammensetzung des Tabaks und den Merkmalen des Rauches; Ber. Inst. Tabakforsch. Dresden 6 (1959) 66-105.

57. Pyriki, C.: Study of soluble carbohydrates in Virginia tobaccos and of the influence of monosaccharides on tobacco quality; Proc. 2nd Int. Sci. Tob. Congr., Brussels, 1958, 582-588.

58. Ramakrishnayya, B. V., N. C. Gopalachari and X. S. N. Murty: A study of some chemical quality indexes of flue-cured tobacco with reference to grades and leaf position on stalk; Indian J. Appl. Chem. 29 (1966) 170-180.

59. Rodriguez, J. L.: Index of quality and aromatization of Cuban tobaccos (Inst. Cubano Invest. Technol.); Ser. Estud. Trabajos Invest. 14 (1960) 57.

60. Sabir, S. S.: Chemical composition of flue-cured tobacco grown in Iraq; Iraq. Chem. Soc. J. 1 (1976) 81-86.

61. Sanaullah, M.: A review of tobacco quality; Sci. Ind. (Karachi) 8 (1971) 140-143.

62. Sastry, A. S., and C. K. Ramakrishna Kurup: Chemical evaluation of the burning quality of cheroot tobacco; J. Sci. Ind. Res. (India) 17B (1958) 499-504.

63. Sastry, A. S., N. C. Gopalachari and K. S. N. Murty: Further studies on some chemical indices with reference to grades and leaf position on stalk; Indian J. Appl. Chem. 32 (1969) 43-51.
64. Sequeiros, J. M., J. A. Galbis and J. Oliver: The effect of the soil on the mineral composition and burning qualities of Spanish tobaccos, I. Tobaccos grown on non-calcareous soils of the extreme zone 8; Bol. Inst. Nacl. Invest. Agron. (Madrid) 17 (1957) 199-230.

65. Shakhnovskii, $L$. N.: Objective factor in sensory strength of tobacco products; Tabak (Mosc.) 1959, 3, 28-29.

66. Shmuk, A. A.: The chemistry and technology of tobacco, Vol. 3; Pishchepromizdat, Moscow, 1953.

67. Takahara, H., T. Shinkai, K. Kumagai and I. Morishita: Studies on tobacco extract, VI. Comparative studies of chemical components related to tobacco smoking quality between domestic and American Burley tobacco leaves; Jpn. Monop. Corp. Cent. Res. Inst. Sci. Pap. 112 (1970) 57-61.

68. Zuykova, E. P., and I. I. Baskin: Smoking qualities and physicochemical properties of raw tobacco from the Krasnodar district; Tabak (Mosc.) 1969, 1, 50-53.

Authors' address:

Philip Morris Research Center,

P. O. Box 26583,

Richmond, Va., 23261, U.S.A. 